\title{
Mineral chemistry and thermobarometry of plutonic, metamorphic and anatectic rocks from the Tueyserkan area (Hamedan, Iran)
}

\author{
Ali A. SEPAHI ${ }^{1, *}$, Kazem BORZOEI ${ }^{1}$ and Seddigheh SALAMI ${ }^{1}$ \\ 1 Department of Geology, Bu-Ali Sina University, Hamedan, Iran
}

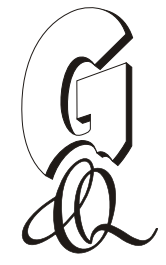

Sepahi A. A., Borzoei K., Salami S. (2013) Mineral chemistry and thermobarometry of plutonic, metamorphic and anatectic rocks from the Tueyserkan area (Hamedan, Iran). Geological Quarterly, 57 (3): 515-526, doi: 10.7306/gq.1108

\begin{abstract}
The study area is a part of the NW to SE striking Sanandaj-Sirjan metamorphic belt in western Iran. The Alvand Pluton, consisting of rocks that range in composition from gabbro to granite, is the major magmatic rock complex of this area. Gabbroic rocks include olivine gabbro, gabbro norite, norite and gabbro. Rocks around the Alvand Pluton were subjected to different $P-T$ conditions due to polymetamorphism. Common metamorphic rocks are meta-pelites, but some meta-psammites, meta-basites and meta-carbonates also occur. Slates, phyllites, schists, migmatites and hornfelses are major rock units of meta-pelites in the metamorphic sequence. Based on mineral chemistry, the highest temperature of crystallisation $\left(1300^{\circ} \mathrm{C}\right)$ was determined for the olivine gabbros, and the lowest temperature $\left(950^{\circ} \mathrm{C}\right.$ ) was calculated for the hornblende-bearing gabbros. Clinopyroxene-plagioclase barometry suggests that pressures near 5 to 6 kbars prevailed during the crystallisation of the various mafic rocks. $P-T$ estimates yield maximum temperatures of $700-750^{\circ} \mathrm{C}$ at $5-6$ kbars for the high-grade metamorphic rocks from the metamorphic aureole around the pluton. These results indicate that the heat released from the Alvand Pluton $\left(T=950-1300^{\circ} \mathrm{C}\right)$, which intruded the metamorphic rocks at middle and upper crustal levels, was sufficient to cause partial melting leading to formation of the metatexites, diatexites and restite-rich S-type granites. During this process, part of the deep-seated gabbro-dioritic rocks were transported to higher crustal levels by viscous, enclave- and crystal-rich granitic magmas of the partial melting zone.
\end{abstract}

Key words: Alvand Pluton, Hamedan, Iran, mineral chemistry, Sanandaj-Sirjan zone, thermobarometry

\section{INTRODUCTION}

The study area is located in the northern Sanandaj-Sirjan zone, western Iran. The Sanandaj-Sirjan zone is part of the Alpine-Himalayan orogenic system extending from NW Iran and west Turkey to SE Iran. Basic petrographic studies on plutonic and metamorphic rocks of the Hamedan region of the northern Sanandaj-Sirjan zone have been published in the papers in Persian (Zareiyan et al., 1971-1974). Additional studies of petrography and petrogenesis of plutonic and metamorphic rocks are discussed in some publications and M.Sc. and Ph.D. theses (Irani, 1993; Sadeghian, 1994; Baharifar, 1997, 2004; Sepahi, 1999, 2008; Badrzadeh, 2002; Sepahi et al., 2004, 2009; Shahbazi, 2010; Shahbazi et al., 2010; Tork, 2011; Borzouei, 2012; Saki et al., 2012). However, the mineral chemistry and thermobarometry of an interesting plutonic and metamorphic sequence from the area north of Tueyserkan have not been studied in detail so far. Therefore, we decided to focus our work on various index minerals from mafic plutonic rocks and their metamorphic aureole from the Tueyserkan area in order to estimate the $P-T$ conditions of magmatism and metamorphism. The major goal was to determine wether the heat pro-

\footnotetext{
* Corresponding author, e-mail: sepahi@basu.ac.ir
}

Received: March 2, 2013; accepted: June 3, 2013; first published online: June 28,2013 vided by the Alvand Pluton was sufficient to cause high temperature metamorphism and anatexis of the metapelites in the region. This was accomplished by using various published thermobarometric calibrations, e.g., garnet-biotite and garnet-cordierite thermometers and garnet-plagioclase-muscovite-biotite (GPMB), garnet-aluminosilicate-quartz-plagioclase (GASP) and garnet-biotite-plagioclase-quartz (GBPQ) barometers (Ferry and Spear, 1978; Perchuk et al., 1985; Aranovich et al., 1988; Hoisch, 1990; Holland and Powell, 1990; Berman, 1991; Dasgupta et al., 1991; Bhattacharya et al., 1992; Kleemann and Reinhardt, 1994; Holdaway, 2000; Henry et al., 2005; Powell and Holland, 2008).

\section{GEOLOGICAL SETTING}

The Sanandaj-Sirjan zone, or Zagros imbricate zone of the Zagros Orogen, Iran (Alavi, 1994, 2004) comprises a metamorphic belt of low- to high-grade regional and contact metamorphic rocks that have been intruded by mafic, intermediate and felsic magmas (Fig. 1). Major magmatism in the Sanandaj-Sirjan zone occurred during the Mesozoic (e.g., Baharifar, 1997, 2004; Sepahi, 1999; Rashidnejad-Omran et al., 2002; Sheikholeslami et al., 2003; Sepahi et al., 2004; Ahmadi-Khalaji et al., 2007). Altogether, the crystallisation ages of the major plutons range from Mesozoic to Paleogene, $\sim 200$ to $\sim 40 \mathrm{Ma}$ (Valizadeh and Cantagrel, 1975; Braud,1987; Masoudi, 1997; Baharifar, 2004; Ahmadi-Khalaji et al., 2007; Arvin et al., 2007; 


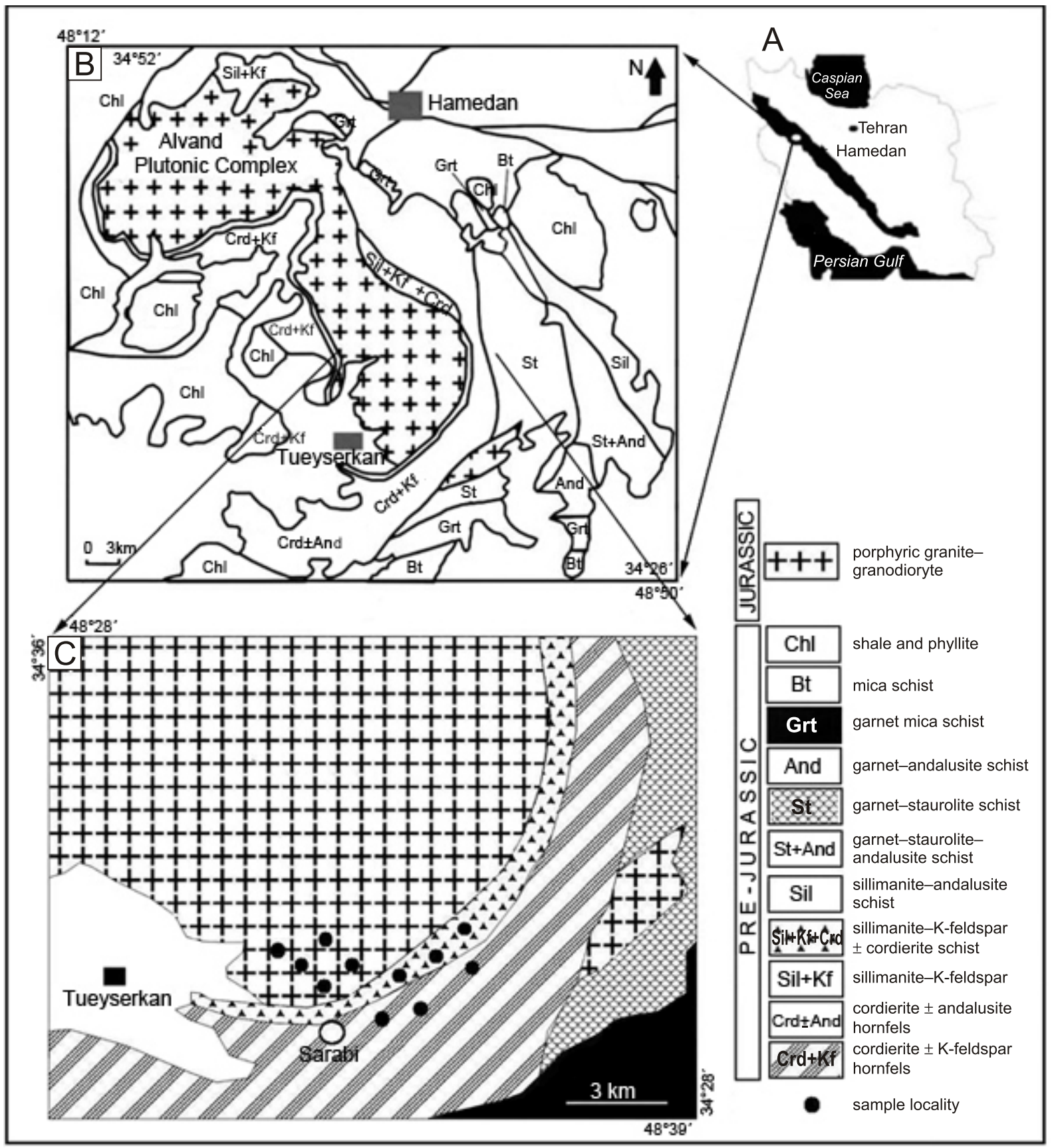

Fig. 1. Simplified map showing the geological setting of the Sanandaj-Sirjan zone, Hamedan region and north of the Tueyserkan area

Shahbazi et al., 2010; Ahadnejad et al., 2011; Mahmoudi et al., 2011; Esna-Ashari et al., 2012). The time span of magmatism in the Sanandaj-Sirjan zone of the Zagros Orogen can be related to different stages of magmatism resulted from opening of an ocean, later subduction of the oceanic crust, and collision and post-collision (post-orogenic) stages of magmatism. Because the plutonic rocks of the area studied are mid-Jurassic in age (Shahbazi et al., 2010), magmatism and metamorphism of the region is attributed to subduction of the Neo-Tethys Ocean beneath the central Iranian micro-continent and to the subsequent collision of the Afro-Arabian continent and Eurasia from Jurassic to Neogene times (e.g., Baharifar, 1997, 2004; Sepahi, 1999; Sepahi et al., 2004; Shahbazi et al., 2010). Sepahi et al. (2004) have referred to an arc-type metamorphism followed by a somewhat higher pressure event.
Plutonic rocks of the Alvand Plutonic Complex, as a major plutonic body of the northwestern Sanandaj-Sirjan zone, have been divided into three rock associations (Sepahi, 2008): gabbros-diorites-tonalites (GDT), porphyritic granodiorites and granites and leucocratic granitoids. The GDT association is composed of olivine gabbro, gabbro, gabbro-norite, quartz gabbro, diorite, quartz diorite and tonalite. In the granodiorite-granite suite, porphyritic monzogranite is the most frequent rock type. Leucocratic granitoids are composed of leucotonalites, leucogranodiorites and leucogranites. U-Pb dating shows a Jurassic crystallisation age for the Alvand Pluton. Gabbros formed at $166.5 \pm 1.8 \mathrm{Ma}$, granites at $163.9 \pm 0.9 \mathrm{Ma}$ and $161.7 \pm 0.6 \mathrm{Ma}$, and leucocratic granitoids at $154.4 \pm 1.3$ and $153.3 \pm 2.7 \mathrm{Ma}$ (Shahbazi et al., 2010). K-Ar cooling ages between 90 and $63 \mathrm{Ma}$ (for micas of the granitic rocks) were reported by Valizadeh and Cantagrel (1975). Rb-Sr ages be- 
tween 89 and $68 \mathrm{Ma}$ (for micas of the granitic rocks) were published by the same authors. Braud (1987) has determined a $\mathrm{K}$-Ar cooling age of $64 \pm 2 \mathrm{Ma}$ for the porphyritic granite of the Alvand Pluton.

Metamorphic rocks of the area are meta-pelites and minor meta-psammites, quartzites, meta-basites, calc schists and calc silicates. Meta-pelites include slate, phyllite, pelitic schist/migmatite and hornfels (Fig. 1). The metamorphic rocks of the Tueyserkan area have been subjected both regional and contact metamorphism. Regional metamorphic zones of chlorite, biotite, garnet, andalusite (chiastolite), sillimanite and sillimanite-( \pm cordierite)-K-feldspar and contact metamorphic zones of cordierite ( \pm andalusite), cordierite-K-feldspar and sillimanite-K-feldspar are widespread around the Alvand Pluton, especially in the Tueyserkan area. A detailed description of metamorphic rocks and zones was undertaken during earlier researches (e.g., Sepahi et al., 2004, 2009).

\section{ANALYTICAL METHODS}

About 100 thin sections from various plutonic and metamorphic rocks were evaluated for petrographic investigation. EPMA analyses of various minerals (Appendices 1-11) were made at the IMPRC, Karaj, Iran, using a Cameca SX100 electron microprobe under $15 \mathrm{kV}$ accelerating voltage, $20 \mathrm{nA}$ beam current and 52-0 $\mu \mathrm{m}$ beam diameter. $A X$ (free download from tjbh url: http://www.esc.cam.ac.uk/astaff/holland/index.html) and THERMOCALC (free download) softwares were used for mineral formulae calculations, $P-T$ estimations and petrogenetic interpretations.

\section{FIELD OBSERVATIONS AND PETROGRAPHY}

Considering that data on the field relations and petrography of the plutonic and metamorphic rocks of the region has been published previously (Sepahi et al., 2004, 2009; Sepahi, 2008, see the section on the geological setting, above), we here only briefly refer to field observations and petrography of the selected rock samples (i.e., we do not present complete descriptions of all of the rock types of the region).

\section{PLUTONIC ROCKS}

Various plutonic rocks, ranging from gabbro to granite, crop out in the Tueyserkan area. These were intruded by aplitic and pegmatitic dikes. The granites contain feldspar megacrysts in some field exposures. They are composed of quartz, K-feldspar, plagioclase and biotite (Fig. 2A); muscovite and zircon are accessory minerals. Some restitic xenocrysts of $\mathrm{Al}_{2} \mathrm{SiO}_{5}$-minerals (andalusite and sillimanite) and garnets occur in these rocks. Mafic rocks include olivine gabbro, gabbro and norite. OIivine gabbro has subhedral granular to intergranular texture and is composed of olivine, clinopyroxene and plagioclase as major minerals and orthopyroxene, amphibole and biotite as minor minerals (Fig. 2B). Plagioclase-olivine coronas occur occasionally. Gabbro has intergranular, ophitic and sub-ophitic textures and is composed of clinopyroxene and plagioclase as major phases (Fig. 2C) and olivine and hornblende as minor minerals. Norite has subhedral granular to sub-ophitic texture and is composed of orthopyroxene and plagioclase (Fig. 2D), minor olivine and clinopyroxene and accessory apatite.

\section{METAMORPHIC ROCKS AND MIGMATITES}

Hornfels and migmatite are the most common metamorphic rocks in the area. Field observations indicate a gradual change in the degree of anatexis from metatexite through diatexite to garnet-bearing granite in the area (Fig. 3) but the order of rock units towards the plutonic bodies is not regular in many outcrops.

In migmatites, partial melting fronts were initiated around various porphyroblasts, especially $\mathrm{Al}_{2} \mathrm{SiO}_{5}$ minerals and cordi-
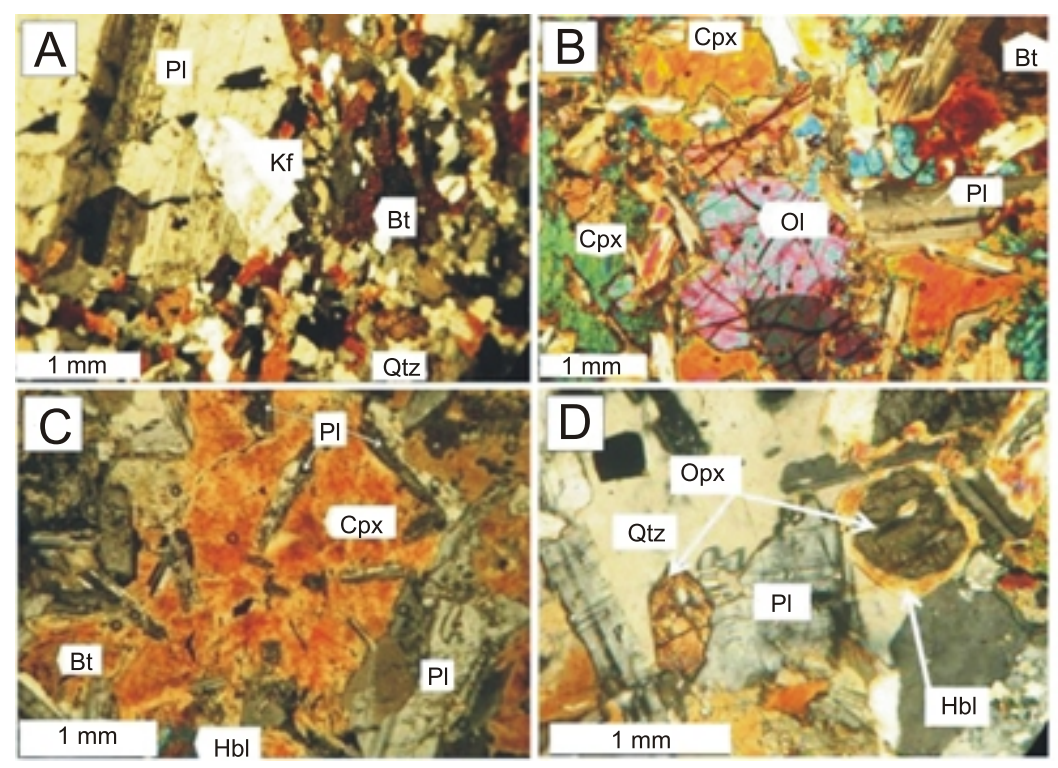

Fig. 2. Photomicrographs of (A) porphyroid granite, (B) olivine gabbro, (C) gabbro and (D) norite

$\mathrm{Bt}$ - biotite, $\mathrm{Cpx}$ - clinopyroxene, $\mathrm{Hbl}$ - hornblende, $\mathrm{Kf}$ - K-feldspar, Ol - olivine, Opx - ortopyroxene, $\mathrm{Pl}$ - plagioklase, Qtz - quartz 

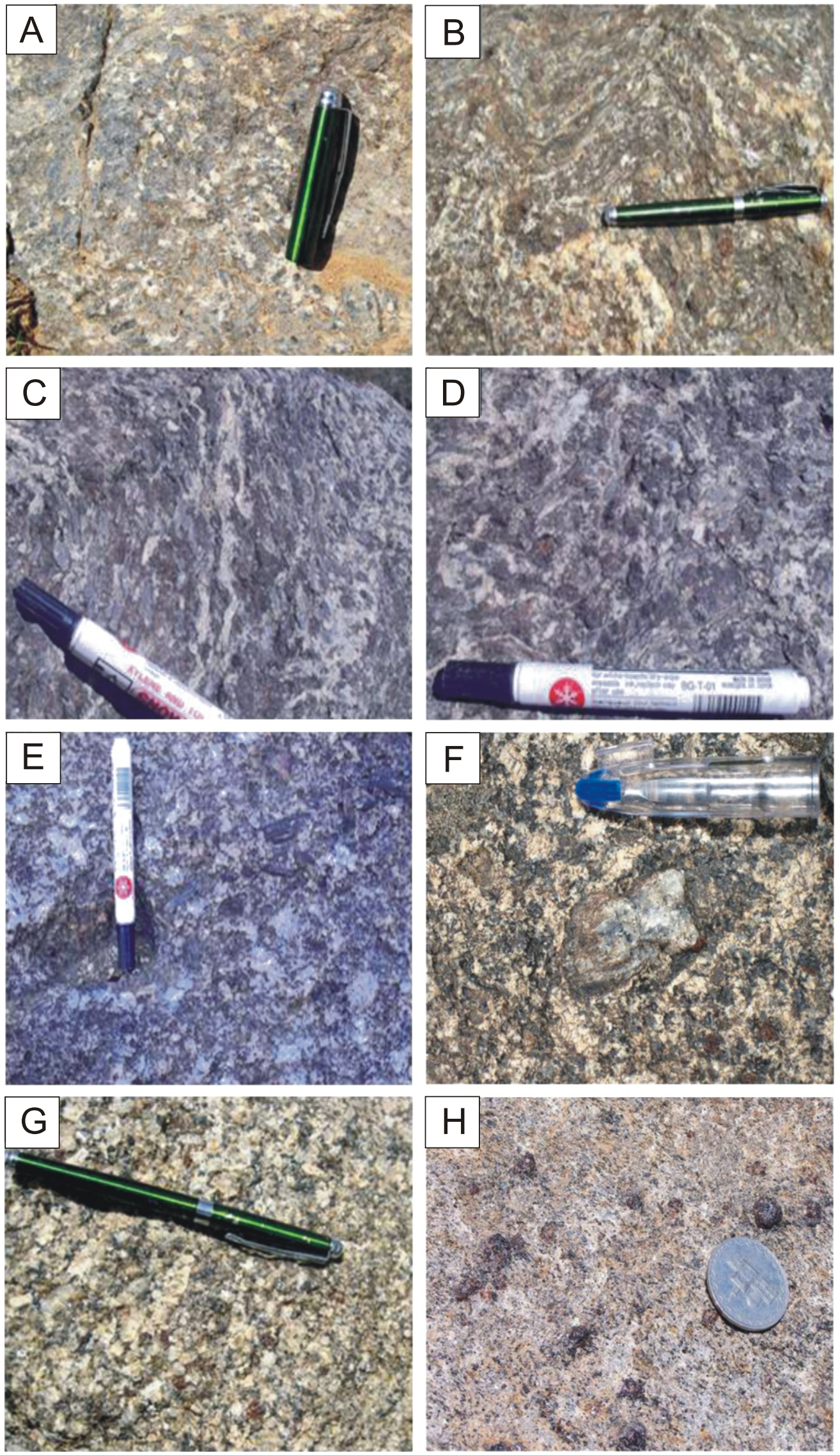

Fig. 3. Gradual changes from metatexite to diatexite to garnet-bearing granite while garnet \pm andalusite/sillimanite porphyroblasts have remained metastable in the anatectic rocks

From $\mathrm{A}$ to $\mathrm{H}$ degree of partial melting is increasing gradually in anatectic rocks; $\mathbf{A}, \mathbf{B}$ - metatexite migmatite, $\mathbf{C}-\mathbf{E}$ - diatexite migmatite, $\mathbf{F}$ - sillimanite-garnet-bearing diatectic granite and $\mathbf{G}, \mathbf{H}-$ garnet-bearing granite; length of scales is: $5 \mathrm{~mm}(A), 200 \mathrm{~mm}(B, G), 100 \mathrm{~mm}(C), 200 \mathrm{~mm}(\mathrm{D}, \mathrm{E}), 40 \mathrm{~mm}(\mathrm{~F})$, diameter of coin is $15 \mathrm{~mm}(\mathrm{H})$ 

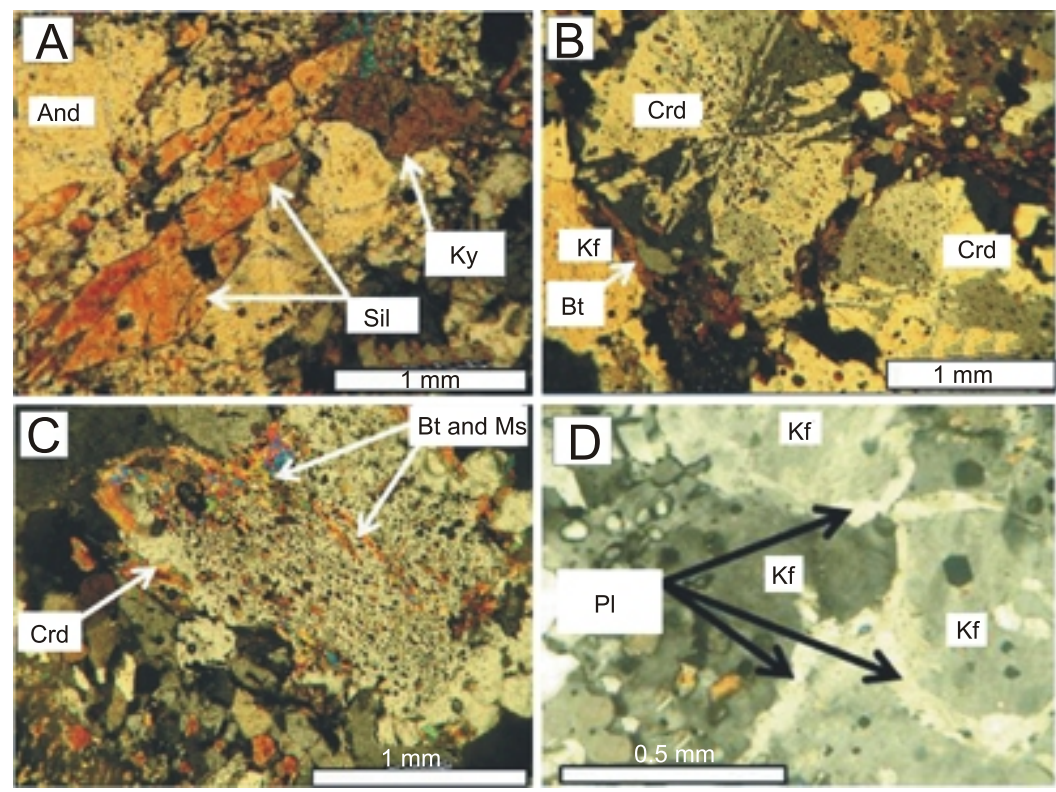

Fig. 4. Photomicrograph of selected metamorphic rocks of the area studied

A-C - hornfelses with various index minerals as indicated by their abbreviations on photos, D - overgrowth of plagioclase on K-feldspar in migmatite; And - andalusite, Crd - cordierite, Ky - kyanite, Ms - muscovite; other explanations as in Figure 2

erite, and then migrated to other parts of the rock. During anatexis, garnet and aluminosilicate (andalusite, sillimanite) porphyroblasts remained partly stable but floated and were re-distributed in the viscous mush when the partial melt reached its critical moving threshold.

Among the hornfelses, garnet-staurolite- $\mathrm{Al}_{2} \mathrm{SiO}_{5}$ and andalusite-fibrolite-cordierite-garnet-bearing hornfels (Fig.4A-C) prevail. The typical mineral assemblage of the first rock type is quartz + biotite + muscovite + andalusite/sillimanite (rarely kyanite) + staurolite + garnet + chlorite \pm spinel, and for the second rock type is quartz + biotite + muscovite + K-feldspar + cordierite \pm andalusite (fibrolite) \pm spinel. Replacement of andalusite by spinel + cordierite coexisting with biotite is common in some metamorphic rocks (see also Saki, 2011). Cordierite-bearing migmatites are widespread but garnet-sillimanite-bearing migmatites occur in some parts of the metamorphic aureole as well. The typical mineral assemblage of this migmatite is quartz + K-feldspar + plagioclase + biotite + garnet \pm sillimanite/andalusite. Overgrowths of sodic plagioclase on K-feldspar occur in places (Fig. 4D). Other migmatite types are spinel-andalusite migmatites, garnet-cordierite migmatites and cordierite-spine migmatites. Cordierite $+\mathrm{K}$-feldspar + sillimanite/andalusite + biotite + plagioclase + quartz \pm garnet \pm spinel is a typical assemblage seen near the plutonic rocks in the Tueyserkan area. For comparison, the mineral assemblage of cordierite-bearing migmatites closely resembles D-1 to D-4 assemblages from the deep-seated Steinach aureole of Oberpfalz, North-East Bavaria, Germany reported by Okrusch $(1969,1971)$.

\section{MINERAL CHEMISTRY}

EPMA analysis on various minerals including olivine, clinopyroxene, orthopyroxene, amphibole, biotite and plagioclase in plutonic rocks and cordierite, garnet, plagioclase, biotite, chlorite, muscovite, staurolite, $\mathrm{Al}_{2} \mathrm{SiO}_{5}$-minerals and spinel in metamorphic rocks are shown in Appendices 1-11.
MINERAL CHEMISTRY OF THE PLUTONIC ROCKS

The results of EPMA analyses for olivine crystals from the gabbroic rocks are given in Appendix 1. Chemical compositions of these crystals lie in the crysolite field. EPMA analyses for clinopyroxene from the same rocks (Appendix 2) plot close to the calcic clinopyroxene (augite) field. Chemical compositions of orthopyroxene crystals (Appendix 3 ) lie in the bronzite, hypersthene and ferrohypersthene fields. EPMA analyses of amphibole crystals (Appendix 4) reveal a typical calcic hornblende composition. EPMA analyses of biotite (Appendix 5) lie in the eastonite-siderophyllite fields near the phlogopite-annite fields. Plagioclase crystals (Appendix 6) from various mafic plutonic rocks lie in the andesine, labradorite and bytownite fields.

MINERAL CHEMISTRY OF THE META-PELITIC METAMORPHIC ROCKS

EPMA analyse have been carried out on cordierite, garnet, spinel, biotite, staurolite, white mica, $\mathrm{Al}_{2} \mathrm{SiO}_{5}$-minerals, chlorite, plagioclase and K-feldspar. Representative results are shown in Appendices 7 to 11. Cordierite has intermediate $\mathrm{Mg}^{\#}$ number (0.489-0.580; Appendix 7, $\left.\mathrm{Mg}^{\#}=\mathrm{Mg} /(\mathrm{Mg}+\mathrm{Fe}+\mathrm{Mn})\right)$. Garnets show zoning in some cases but they are almandine-rich pyralspites with small amounts of grossular in their compositions $\left(\mathrm{X}_{\text {Alm }}\right.$ - almandine content in garnet $=61.8-79.0 \%$, Appendix 8). Staurolite crystals are Fe-rich and their Mg numbers $\left(\mathrm{Mg}^{\#}\right)$ are $0.121-0.132 . \mathrm{Al}_{2} \mathrm{SiO}_{5}$ minerals have minor to trace amounts of $\mathrm{Fe}$ and $\mathrm{Mg}$ as inpurities (FeO $-0.00-1.12 \mathrm{wt} . \%$ and $\mathrm{MgO}-0.02-0.29$ wt.\%). Spinel is Fe-rich, thus hercynitic with minor amounts of $\mathrm{Cr}, \mathrm{Mg}$ and $\mathrm{Mn}$ in composition. $\mathrm{Fe} /(\mathrm{Fe}+\mathrm{Mg})$ in biotites is $0.57-0.68$. Chemical compositions of biotite crystals (Appendix 9) lie in the siderophyllite and annite fields. White mica compositions lie in the common muscovite range but they also contain minor amounts of $\mathrm{Na}_{2} \mathrm{O}$ (Appendix 10) whereas chlorite compositions plot in the rhipidolite field. Chemical compositions of plagioclase lie in the oligoclase-andesine field (Ap- 
pendix 11). K-feldspar crystals contain up to 90 wt. \% orthoclase component.

\section{THERMOBAROMETRY}

In thermobarometric studies, we may determine the $P-T$ conditions which rocks sustained during equilibrium crystallisation. For this purpose, petrographic studies and determination of the chemical composition of individual minerals by various analytical techniques such as EPMA are essential. Several geothermometers and geobarometers have been introduced by geologists in recent years. We have examined one thermometric (i.e., clinopyroxene-orthopyroxene thermometry) and one barometric (clinopyroxene-plagioclase barometry) method to obtain $P-T$ conditions of crystallisation of the gabbroic rocks. Then, we calculated $P-T$ conditions of the metapelitic metamorphic rocks of the region using the mineral chemistry of the index minerals. In this regard, it was important to us to be sure that if the geothermobarometric results are in accordance with the idea that the Alvand Pluton has been a possible heat source for metamorphism and anatexis in the region.

\section{THERMOBAROMETRY OF THE MAFIC PLUTONIC ROCKS}

Mineral chemistry of orthopyroxene, clinopyroxene, amphibole and plagioclase used to determine the $P-T$ conditions during the crystallisation of the gabbroic rocks.

\section{CLINOPYROXENEO-RTHOPYROXENE THERMOMETRY}

Assuming a pressure of $5 \mathrm{kbar}$ (see section on barometry, below) the clinopyroxene-orthopyroxene thermometer of Lindsley (1983) yields crystallisation temperatures of $1200-1300^{\circ} \mathrm{C}$ for the olivine gabbro and $900-1100^{\circ} \mathrm{C}$ for the gabbro (Fig. 5).

\section{CLINOPYROXENEP-LAGIOCLASE BAROMETRY}

The application of the barometric equations of McCarthy and Patino-Douce (1998) for coexisting clinopyroxene and plagioclase:

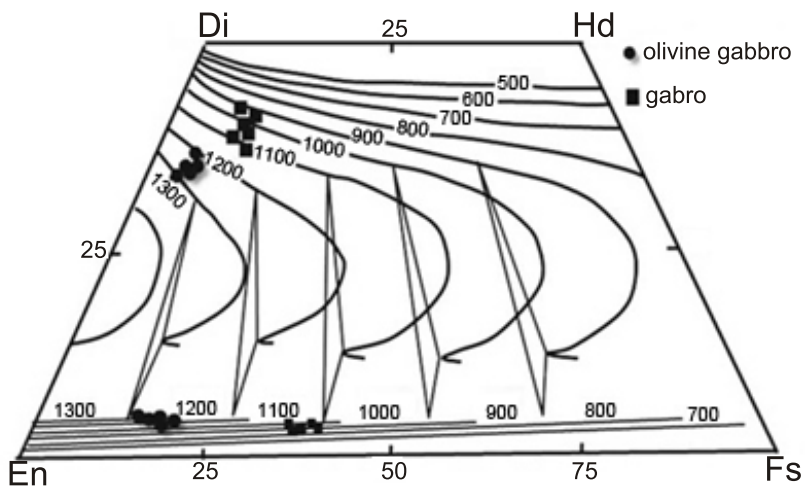

Fig. 5. Plot of composition of orthopyroxene and clinopyroxene on a $\mathrm{Di}-\mathrm{Hd}-\mathrm{En}-\mathrm{Fs}$ rectangle with solvus curves (Lindsley, 1983)

$$
P=[5.066 \pm 0.760+((1300 \pm 800 / T)-\ln K) /(276 \pm 16)]
$$

where: $T$ - temperature $\pm 2.5^{\circ} \mathrm{C}, P$ - pressure [kbar], $K=\alpha_{\mathrm{An}}(\mathrm{PI}) / \alpha_{\text {Cats }}(\mathrm{Cpx}), K$ results in pressure estimates between 5.5 and $6.5 \mathrm{kbars}, \alpha_{\mathrm{An}}$ and $\alpha_{\text {cats }}$ are anorthite activity in plagioclase and Ca-tschermak activity in $\mathrm{Cpx}$, respectively.

$$
P=\{([6.330 \pm 0.116]-\ln K) /(301 \pm 9)\} \times T[ \pm 1.0 \mathrm{kbar}]
$$

We have considered the rim composition of plagioclase crystals for thermobarometric calculations where these are zoned.

\section{THERMOBAROMETRY OF THE METAPELITIC ROCKS}

Using the compositions of various index minerals of the meta-pelitic rocks, obtained from EPMA analyses, we employed various thermometric and barometric methods to constrain the $P-T$ conditions during metamorphism.

\section{Ti IN BIOTITE THERMOMETRY}

Biotite is one of the host minerals for $\mathrm{Ti}$ in metamorphic rocks, the concentration of which is controlled by temperature. According to Henry and Guidotti (2002) and Henry et al., (2005), the following equation can be used to calculate temperature:

$$
T=\left\{\left[\ln (\mathrm{Ti})-a-c\left(\mathrm{X}_{\mathrm{Mg}}\right)^{3}\right] / b\right\}^{0.333}
$$

where: $a=-2.3594, b=4.6482 \times 10^{-9}, c=-1.7283, X_{M g}-$ $\mathrm{Mg} /(\mathrm{Mg}+\mathrm{Fe})$

On the basis of this equation, temperatures between 550 to $575^{\circ} \mathrm{C}$ for the garnet-staurolite hornfels and 675 to $725^{\circ} \mathrm{C}$ for the mesosome of the migmatitic rocks were obtained (Fig. 6).

GARNET-BIOTITE AND GARNET-CORDIERITE THERMOMETERS

According to Ferry and Spear (1978), $\mathrm{Fe}^{2+}$ and $\mathrm{Mg}^{2+}$ exchange between garnet and biotite is temperature-dependent.

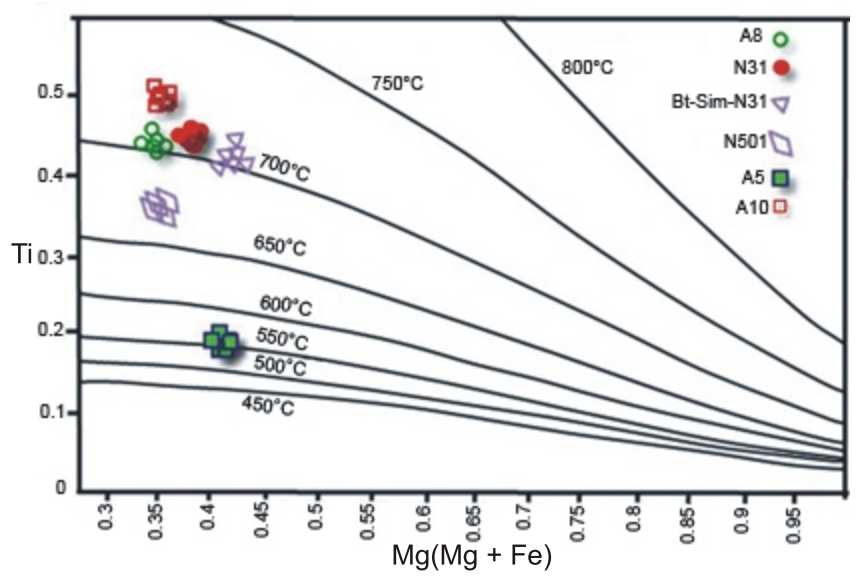

Fig. 6. Plot of amounts of $\mathrm{Ti}$ versus $\mathrm{Mg} /(\mathrm{Mg}+\mathrm{Fe})$ for biotites of the contact metamorphic rocks 
This cation exchange can be expressed by the following reaction: $\mathrm{Mg}_{3} \mathrm{Al}_{2} \mathrm{Si}_{3} \mathrm{O}_{12}$ (pyrope) $+\mathrm{KFe}_{3} \mathrm{AlSi}_{3} \mathrm{O}_{10}(\mathrm{OH})_{2}$ (annite) $=\mathrm{Fe}_{3} \mathrm{Al}_{2} \mathrm{Si}_{3} \mathrm{O}_{12}$ (almandine) $+\mathrm{KMg}_{3} \mathrm{AlSi}_{3} \mathrm{O}_{10}(\mathrm{OH})_{2}$ (phlogopite).

The calibration by Kleemann and Reinhardt (1994) was used for temperature calculation related to this cation exchange reaction. Temperatures between 558 and $688^{\circ} \mathrm{C}$ for hornfelses and $759-790^{\circ} \mathrm{C}$ for migmatitic rocks were obtained, which are in accordance with the observed mineralogical assemblages of these rocks. The garnet-cordierite thermometer (e.g., Aranovich and Podlesskii, 1989; Dwivedi, 1996) gave temperatures of 780 to $785^{\circ} \mathrm{C}$, for migmatitic rocks (Table 1).

BAROMETRY

Various geobarometers such as garnet-plagioclase-muscovite-biotite (GPMB), garnet-aluminosilicate-quartz-plagioclase (GASP) and garnet-biotite-plagioclase-quartz (GBPS or GPBQ) were employed to estimate the pressure(s) of metamor-

Table 1

Results of geothermometry for the garnet-bearing hornfels and migmatite using various calibrations

\begin{tabular}{|l|c|c|c|}
\hline \multicolumn{1}{|c|}{ Method } & $\begin{array}{c}\text { Garnet-cordierite } \\
\text { thermometry }\end{array}$ & \multicolumn{2}{|c|}{ Garnet-biotite thermometry } \\
\hline $\begin{array}{c}\text { Sample/ } \\
\text { calibration }\end{array}$ & $\begin{array}{c}\text { migmatite } \\
\text { (N31) }\end{array}$ & $\begin{array}{c}\text { migmatite } \\
\text { (N31) }\end{array}$ & $\begin{array}{c}\text { hornfels } \\
\text { (A5) }\end{array}$ \\
\hline A & 848 & 889 & 654 \\
\hline B & 779 & 824 & 639 \\
\hline C & 798 & 759 & 558 \\
\hline D & 785 & 803 & 642 \\
\hline E & 786 & 842 & 631 \\
\hline F & 810 & 820 & 688 \\
\hline
\end{tabular}

Garnet-biotite thermometers: A - Thompson (1976), B - Perchuk et al. (1985), C - Aranovich et al. (1988), D - Dasgupta et al. (1991), E - Holdaway (2000), F - Dwivedi et al. (2007); garnet-cordierite thermometers: A - Thompson (1976), B - Bahttacharya et al. (1992), C - Perchuk (1991), D - Aranovich and Podlesskii (1989), E - Dwivedi (1996), F - Dwivedi et al. (1998) phism. In the GPMB (garnet-plagioclase-muscovite-biotite) barometer, the following reactions were considered:

$\mathrm{Grs}+\mathrm{Prp}+\mathrm{Ms}=3 \mathrm{An}+\mathrm{Phl}$

$\mathrm{Grs}+\mathrm{Alm}+\mathrm{Ms}=3 \mathrm{An}+\mathrm{Ann}$

Alm + Phl $=$ Prp + Ann

(Mineral name abbreviations in these equations are from Whitney and Evans, 2010).

For the minerals from the Alvand country rocks the various calibrations of the GPMB barometer yield pressures between of 4.5 to 6 kbars for hornfels and migmatite (Table 2). In the GASP barometer the essential reference reaction is: Sill $+\mathrm{Qtz}+\mathrm{Grt}=$ An. By using the chemical compositions of minerals in various calibrations for GASP, pressure estimations for hornfels and migmatite are various but lie in a range between 4.4 to 6.8 kbars (Table 2).

The GBPQ barometry is based on the following Mg- and Fe-model equilibria (e.g., Hoisch, 1990): $\mathrm{Mg}_{3} \mathrm{Al}_{2} \mathrm{Si}_{3} \mathrm{O}_{12}$ (pyrope) + $2 \mathrm{Ca}_{3} \mathrm{Al}_{2} \mathrm{Si}_{3} \mathrm{O}_{12}$ (grossular) $+3 \mathrm{KMg}_{2} \mathrm{Al}\left(\mathrm{Si}_{2} \mathrm{Al}_{2}\right) \mathrm{O}_{10}(\mathrm{OH})_{2}$ (eastonite) $+6 \mathrm{SiO}_{2}$ (quartz) $=6 \mathrm{CaAl}_{2} \mathrm{Si}_{2} \mathrm{O}_{8}$ (anorthite) $+3 \mathrm{KMg}_{3} \mathrm{AlSi}_{3} \mathrm{O}_{10}(\mathrm{OH})_{2}$ (phlogopite) and $\mathrm{Fe}_{3} \mathrm{Al}_{2} \mathrm{Si}_{3} \mathrm{O}_{12}$ (almandine) $+2 \mathrm{Ca}_{3} \mathrm{Al}_{2} \mathrm{Si}_{3} \mathrm{O}_{12}$ (grossular) $\left.\left.+3 \mathrm{KFe}_{2} \mathrm{Al}\right) \mathrm{Si}_{2} \mathrm{Al}_{2}\right) \mathrm{O}_{10}(\mathrm{OH})_{2}$ (siderophyllite) $+6 \mathrm{SiO}_{2}$ (quartz) $=6 \mathrm{CaAl}_{2} \mathrm{Si}_{2} \mathrm{O}_{8}$ (anorthite) $+3 \mathrm{KFe}_{3} \mathrm{AlSi}_{3} \mathrm{O}_{10}(\mathrm{OH})_{2}$ (annite) . By using the chemical compositions of minerals in GBPQ, pressures estimated for hornfels and migmatite are between 4.9 to 5.5 kbars (Table 2).

\section{THERMOCALC}

In this method, equilibrium curves of various possible reactions between minerals are used for estimation of $P-T$ conditions. To achieve this goal the TC3.2 and AX programs were applied (see analytical method section above, for address). The results of $P-T$ estimation obtained by the THERMOCALC program for various rocks are shown in Figures $7-10$. For the garnet-staurolite hornfels temperatures of $620-650^{\circ} \mathrm{C}$ (at $\sim 5 \mathrm{kbar}$, Figs. 7 and 8) were obtained. The spinel-cordierite-bearing sample yielded temperatures of $720-760^{\circ} \mathrm{C}$ (at $4.5-5.5 \mathrm{kbars}$, Fig. 9) and the garnet-cordierite-bearing sample $\sim 750^{\circ} \mathrm{C}$ (at $5.0-5.5$ kbars, Fig. 10). The estimated temperatures for various hornfelses are $560-630^{\circ} \mathrm{C}$ at pressures of $4-5.5$ kbars. These temperatures extend up to $700-800^{\circ} \mathrm{C}$ for migmatitic rocks.

Table 2

Results of geobarometry of the garnet-bearing hornfels and migmatite using various calibrations

\begin{tabular}{|l|c|c|c|c|c|}
\hline \multicolumn{1}{|c|}{ Method } & \multicolumn{2}{|c|}{ GASP } & GPMB & \multicolumn{2}{c|}{ GPBQ } \\
\hline $\begin{array}{c}\text { Sample/ } \\
\text { Calibration }\end{array}$ & $\begin{array}{c}\text { hornfels } \\
\text { (A5) }\end{array}$ & $\begin{array}{c}\text { migmatite } \\
\text { (N31) }\end{array}$ & $\begin{array}{c}\text { hornfels } \\
\text { (A5) }\end{array}$ & $\begin{array}{c}\text { hornfels } \\
\text { (A5) }\end{array}$ & $\begin{array}{c}\text { migmatite } \\
\text { (N31) }\end{array}$ \\
\hline A & 5.8 & 5.8 & 4.1 & 5.5 & 5.1 \\
\hline B & 5.2 & 6.2 & 4.1 & 5.1 & 4.9 \\
\hline C & 4.4 & 5.7 & 4.5 & - & - \\
\hline D & 6.6 & 6.8 & 4.8 & - & - \\
\hline E & 6.1 & 6.2 & 4.6 & - & - \\
\hline
\end{tabular}

GASP: A - Berman and Aranovich (1996), B - Hodges and Spear (1982), C - Ganguly et al. (1996), D - Koziol and Newton (1988), E - Holland and Powell (1990); GPMB: A Ghent and Stout (1981), B - Holland and Powell (1995), C - Bhattacharya et al. (1992), D - Hodges and Crowley (1985) (Fe), E - Hodges and Crowley (1985) (Mg); GPBQ: A Hoisch (1990) (Mg), B - Hoisch (1990) (Fe) 


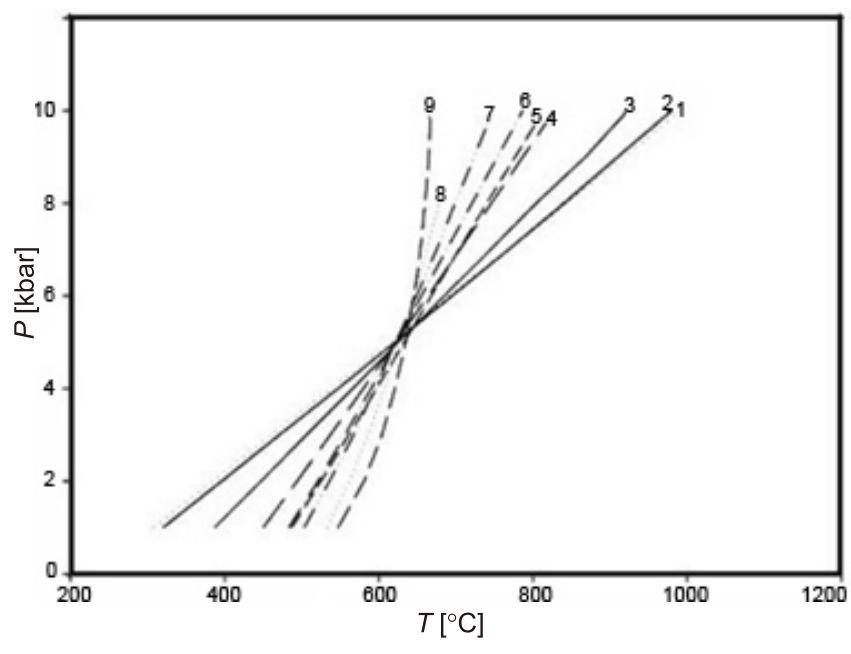

Fig. 7. $P-T$ conditions obtained by the THERMOCALC program for the garnet-staurolite-bearing rocks using the chemical compositions of rims of garnet and staurolite crystals

$1-\mathrm{Grs}+2 \mathrm{And}+\mathrm{Qz}=3 \mathrm{An} ; 2-32 \mathrm{Alm}+23 \mathrm{And}+75 \mathrm{Clc}=$ $125 \mathrm{Prp}+24 \mathrm{Fst}+252 \mathrm{H}_{2} \mathrm{O} ; 3-69 \mathrm{Clc}+6 \mathrm{Fst}+117 \mathrm{Qz}=$ $115 \mathrm{Prp}+24 \mathrm{Fst}+252 \mathrm{H}_{2} \mathrm{O} ; 4-4 \mathrm{Phl}+96 \mathrm{Ky}+3 \mathrm{Cel}=5 \mathrm{Prp}+7 \mathrm{Ms} ; \mathbf{5}-$ $\mathrm{Phl}+3 \mathrm{Ame}+9 \mathrm{Qz}=5 \mathrm{Prp}+\mathrm{Ms}+12 \mathrm{H}_{2} \mathrm{O} ; 6-62 \mathrm{Ame}+53 \mathrm{Eas}+$ $10 \mathrm{Mst}+228 \mathrm{H}_{2} \mathrm{O} ; 7-25 \mathrm{Grs}+8 \mathrm{Alm}+96 \mathrm{And}+12 \mathrm{H}_{2} \mathrm{O}=75 \mathrm{An}+\mathrm{Fst}+$ Sil; $8-\operatorname{Prp}+2 \mathrm{Pg}+3 \mathrm{Qz}=3 \mathrm{An}+2 \mathrm{Ab}+\mathrm{H}_{2} \mathrm{O} ; \mathbf{9}$ $64 \mathrm{Alm}+318 \mathrm{And}+75 \mathrm{Ame}=100 \mathrm{Prp}+48 \mathrm{Fst}+204 \mathrm{H}_{2} \mathrm{O}$

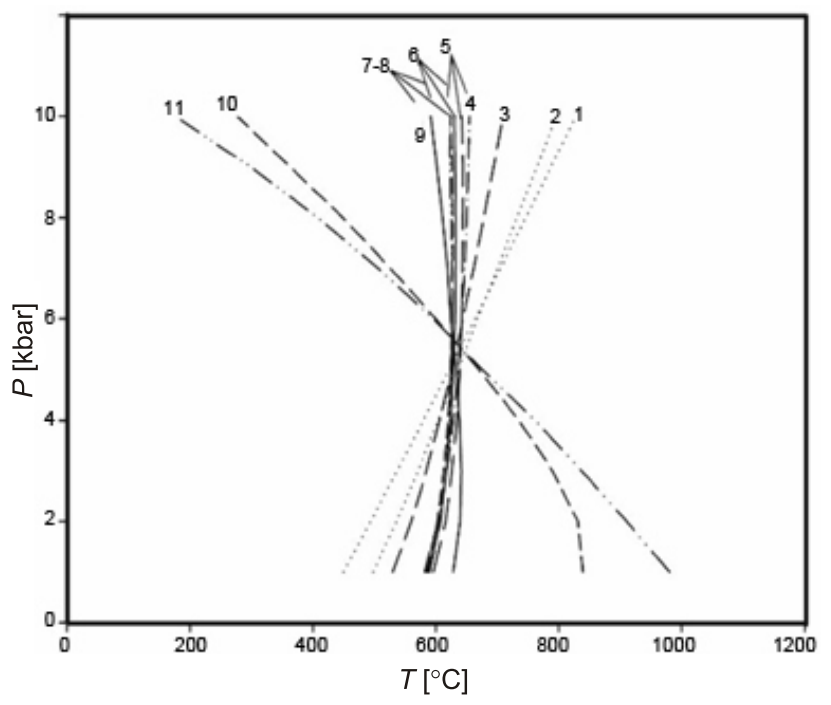

Fig. 8. $P-T$ conditions obtained by the THERMOCALC program for the garnet-staurolite-bearing rocks by using the chemical compositions of cores of the garnet and staurolite crystals

$1-23 \mathrm{Ann}+6 \mathrm{Fst}+48 \mathrm{Qz}=31 \mathrm{Alm}+23 \mathrm{Ms}+12 \mathrm{H}_{2} \mathrm{O} ; 2-51 \mathrm{Alm}+$ $48 \mathrm{Pg}+8 \mathrm{Clim}=17 \mathrm{Grs}+48 \mathrm{Ab}+10 \mathrm{Mst}+6 \mathrm{H}_{2} \mathrm{O} ; 3-8 \mathrm{Grs}+46 \mathrm{Pg}+$ $21 \mathrm{Qz}=46 \mathrm{Ab}+6 \mathrm{Mst}+34 \mathrm{H}_{2} \mathrm{O} ; 4-26 \mathrm{Ab}+7 \mathrm{Clc}=24 \mathrm{Mst}=17 \mathrm{Prp}+$ $26 \mathrm{Pg}+10 \mathrm{H}_{2} \mathrm{O} ; \mathbf{5}-\mathrm{Grs}+2 \mathrm{Pg}+3 \mathrm{Qz}=3 \mathrm{An}+2 \mathrm{Ab}+2 \mathrm{H}_{2} \mathrm{O} ; \mathbf{6}-23 \mathrm{Grs}$ $+6 \mathrm{Fst}+48 \mathrm{Qz}=8 \mathrm{Alm}+69 \mathrm{An}+12 \mathrm{H}_{2} \mathrm{O} ; 7-\mathrm{Grs}+3 \mathrm{Eas}+2 \mathrm{Qz}=\mathrm{Prp}+$ $3 \mathrm{An}+3 \mathrm{Cel} ; 8-17 \mathrm{Grs}+8 \mathrm{Ame}+20 \mathrm{Ms}+2 \mathrm{Mst}=20 \mathrm{Eas}+51 \mathrm{An}+$ $36 \mathrm{H}_{2} \mathrm{O} ; \mathbf{9}-159 \mathrm{An}+48 \mathrm{Ame}=4 \mathrm{Prp}+53 \mathrm{Grs}+18 \mathrm{Ms}+156 \mathrm{H}_{2} \mathrm{O} ; 10-$ $109 \mathrm{Grs}+192 \mathrm{Clc}+66 \mathrm{St}=88 \mathrm{Alm}+327 \mathrm{An}+240 \mathrm{Ams}+60 \mathrm{H}_{2} \mathrm{O} ; 11-$ $\mathrm{Prp}+2 \mathrm{Grs}+3 \mathrm{Eas}+6 \mathrm{Qz}=3 \mathrm{Phl}+6 \mathrm{An}+53 \mathrm{H}_{2} \mathrm{O}$

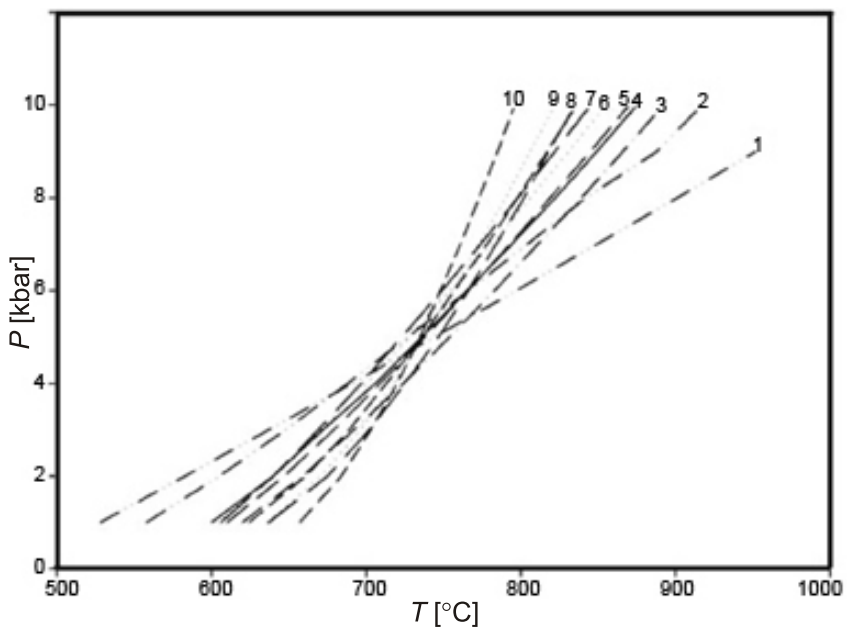

Fig. 9. P-T conditions obtained by the THERMOCALC program for rocks which have spinel-cordierite intergrowths

$1-\mathrm{Spl}+5 \mathrm{Phl}+10 \mathrm{And}=3 \mathrm{Crd}+3 \mathrm{Eas} ; 2-15 \mathrm{Her}+\mathrm{Phl}=3 \mathrm{Spl}+\mathrm{Ann}$; $3-3 \mathrm{Hc}+2 \mathrm{Phl}+15 \mathrm{Qz}=3 \mathrm{Crd}+2 \mathrm{Ann} ; \mathbf{4}-3 \mathrm{Her}+16 \mathrm{Phl}+30 \mathrm{And}=$ $9 \mathrm{Crd}+\mathrm{Ann}+15 \mathrm{Eas} ; \mathbf{5}-2 \mathrm{Ann}+6 \mathrm{Pg}+15 \mathrm{Qz}=3 \mathrm{Fcrd}+6 \mathrm{Ab}+2 \mathrm{Sa}+$ $8 \mathrm{H}_{2} \mathrm{O} ; 6-3 \mathrm{Fcrd}+6 \mathrm{Eas}+21 \mathrm{Qz}=6 \mathrm{Cerd}+2 \mathrm{Ann}+4 \mathrm{Sa}+4 \mathrm{H}_{2} \mathrm{O} ; 7$ $3 \mathrm{Fcrd}+6 \mathrm{Eas}=12 \mathrm{Spl}+2 \mathrm{Ann}+4 \mathrm{Sa}+4 \mathrm{H}_{2} \mathrm{O} ; 8-2 \mathrm{Her}+5 \mathrm{Qz}=\mathrm{Fcrd}$; $9-\mathrm{Ann}+3 \mathrm{Sil}=3 \mathrm{Hc}+3 \mathrm{Qz}+\mathrm{San}+\mathrm{H}_{2} \mathrm{O} ; \mathbf{1 0}-2 \mathrm{Phl}+\mathrm{Ann}+15 \mathrm{Pg}=$ $6 \mathrm{Hc}+2 \mathrm{Phl}+15 \mathrm{Sil}+15 \mathrm{Ab}+15 \mathrm{H}_{2} \mathrm{O}$

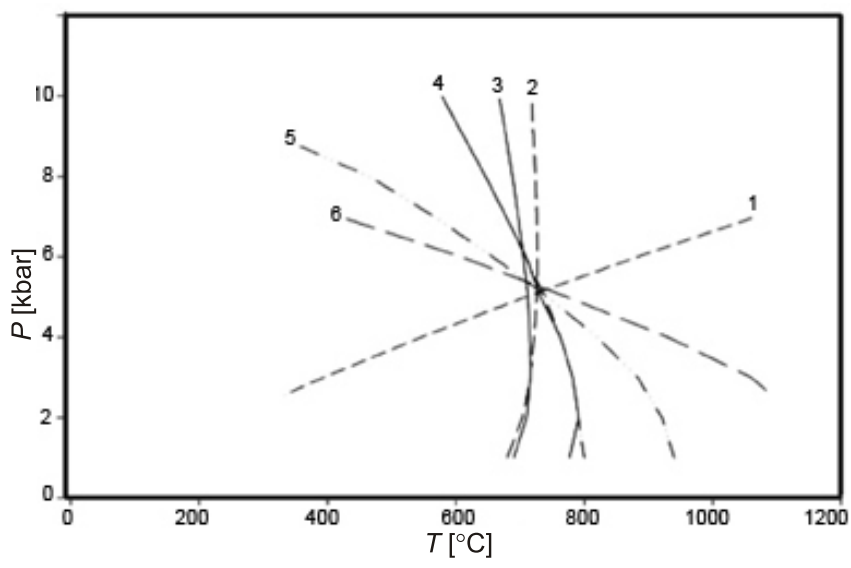

Fig. 10. $P-T$ conditions obtained by the THERMOCALC program for the garnet-cordierite-bearing migmatitic rocks

$1-3 \mathrm{Fcrd}+2 \mathrm{Ame}+7 \mathrm{Qz}=4 \mathrm{Crd}+2 \mathrm{Alm}+8 \mathrm{H}_{2} \mathrm{O} ; 2-12 \mathrm{Sil}+\mathrm{Prp}+$ $5 \mathrm{Phl}=4 \mathrm{Crd}+5 \mathrm{Eas} ; 3-4 \mathrm{Sil}+2 \mathrm{Prp}+5 \mathrm{Qz}=3 \mathrm{Crd} ; \mathbf{4}-4 \mathrm{Crd}+7 \mathrm{Phl}+$ $6 \mathrm{Ame}=13 \mathrm{Prp}+7 \mathrm{Eas}+24 \mathrm{H}_{2} \mathrm{O} ; \mathbf{5}-2 \mathrm{Sa}+2 \mathrm{Ann}+3 \mathrm{Ame}+9 \mathrm{Qz}+$ $3 \mathrm{Fcrd}+4 \mathrm{Phl}+10 \mathrm{H}_{2} \mathrm{O} ; 6-12 \mathrm{Crd}+2 \mathrm{Phl}+18 \mathrm{Ame}=39 \mathrm{Prp}+8 \mathrm{Ann}+$ $2 \mathrm{Feas}+72 \mathrm{H}_{2} \mathrm{O}$ 


\section{DISCUSSION}

We estimated temperatures for various metamorphic rocks near the gabbroic bodies. Estimated temperatures for hornfelses are $560-630^{\circ} \mathrm{C}$ at pressures of $4-5.5 \mathrm{kbars}$. Temperatures extend up to $700-800^{\circ} \mathrm{C}$ for migmatitic rocks near the gabbroic plutonic rocks. These estimated $P-T$ conditions and the results of previous studies (e.g., Sepahi, 1999, 2008; Baharifar, 2004; Sepahi et al., 2004, 2009) indicate that the Alvand aureole is a mesozonal deep-seated aureole with conditions that are different from those of shallow-level epizonal aureoles. It is obvious that in this deep-seated contact aureole there is an increase in temperature towards the igneous contact, but the order of metamorphic zones have been complicated due to younger tectonic events in the region.

Our thermobarometric results are important because there have been disputes among geologists who studied partial melting in the Hamedan area and the resulting rocks such as anatectic migmatites (metatexites and diatexites) and restite-rich S-type granites in terms of the possible source of the heat (e.g., Baharifar, 2004; Sepahi, 2008; Sepahi et al., 2009; Saki et al., 2012). Sepahi (1999) reported migmatites in the region for the first time but he argued that the heat of the plutonic bodies at the present outcrop level of the crust was not sufficient to cause partial melting in the contact aureole (Sepahi, 2008). This interpretation was raised from field observations that show that major anatectic migmatites are located near the granitic plutons (e.g., in the Simin Valley south of Hamedan) but are absent near the contact with the gabbroic rocks (e.g., near Cheshmeh-Ghassaban village, west of Hamedan). Baharifar (2004) considered that the heat of the granitic intrusions could have been responsible for anatexis in the metapelites. Here we to postulate the interpretation that the heat for anatexis came from crystallising gabbroic melt because it seems rather unlikely that granitic intrusions with an intrusion temperature between 700 and $800^{\circ} \mathrm{C}$ would cause anatexis sufficiently intense to produce widespread anatectic migmatites in the Tueyserkan and adjacent areas of the Hamedan region.

The geochronological order of the mafic and felsic plutonism (gabbroic intrusions at $166.5 \pm 1.8 \mathrm{Ma}$ and formation of S-type granite at $163.9 \pm 0.9 \mathrm{Ma}$ and $161.7 \pm 0.6 \mathrm{Ma}$; Shahbazi et al., 2010) indicates an evolutionary path similar to that proposed by Hyndman (1985) for magmatism and metamorphism in a continental arc setting. According to this model, hot fluids released by dehydration reactions from hydrous minerals together with the heat of mafic magmas (such as gabbros) are responsible for metamorphism, partial melting and generation of anatectic migmatites (metatexites and diatexites) and granitic magmas (the S-type monzogranites of the study area) in the arc crust. In this model, the felsic anatectic magmas end up as high level plutons piercing through the metamorphic pile of the arc environment, and thereby postdating the regional metamorphism by a brief interval. Our estimated temperatures for mafic plutonic rocks $\left(\sim 1300^{\circ} \mathrm{C}\right)$ as possible source of the heat, and the maximum temperature estimated for anatectic melts $\left(\sim 750^{\circ} \mathrm{C}\right)$ are in accordance with the model of plutonic-metamorphic events suggested by Hyndman (1985).

\section{CONCLUSIONS}

EPMA analyses of minerals from gabbroic rocks of the Alvand Pluton indicate that olivine is $\mathrm{FO}_{71-72}$, clinopyroxene is almost augite, amphiboles are calcic (hornblende-tremolite-actinolite), biotite is eastonite-siderophyllite and plagioclase is andesine-labradorite-bytownite in composition. These mineral compositions indicate a typical sub-alkaline magma. Crystallisation temperatures for these rocks were $900-1300^{\circ} \mathrm{C}$. These rocks crystallised at pressures of around 5-6 kbars. In the metamorphic rocks, cordierite has intermediate $\mathrm{Mg}^{\#}$, garnet is almandine-rich, spinel is Fe-rich (hercynitic), staurolite is Fe-rich, biotite is siderophyllite-annite and plagioclase is oligoclase-andesine in composition.

Our study reveals that the gabbroic intrusions at deeper levels of the crust (up to $1300^{\circ} \mathrm{C}$ at $>5 \mathrm{kbar}$ equal to $>15 \mathrm{~km}$ depth) could have acted as the essential heat source for the intense anatexis and formation of the anatectic migmatites. Thus, the S-type granites are not considered as the heat suppliers of the anatexis but as the final products of an intense partial melting process caused by substantial advective heating by the gabbroic intrusion. The subsequent intrusion of some anatectic magmas to the upper levels of the crust caused reheating in the metamorphic rocks close by.

According to Sepahi (2008) and Sepahi et al. (2009) and the results of this study, plutonism and metamorphism in the Hamedan region, especially in the Tueyserkan area, occurred in the middle crust $(15-20 \mathrm{~km})$ of a continental margin which subsequently evolved in a continental collision environment (i.e., collision zone of the Afro-Arabian continent and the central Iranian micro-continent as a southern part of the Eurasia super-continent). The signatures of a later, slightly higher pressure event on previous high $T$-low $P$ arc-type metamorphism (Sepahi et al., 2004), can be attributed to this type of geological evolution in the region.

Field observations show that the exposed volumes of the gabbro-dioritic rocks are not adequate to cause widespread migmatisation and production of S-type granites in the Tueyserkan area. We therefore suggest the existence of larger volumes of mafic intrusions at deeper levels, responsible for anatexis and granitisation. According to field observations, megablocks and enclaves of such intrusions have been transported to higher levels of the crust by restite-rich, crystal-laden viscous granitic intrusions with their roots possibly located in the partial melting zone around mafic intrusions at deeper levels of the crust.

Acknowledgements. We thank Prof. M. Moazzen and Prof. W. Siebel for their reviews, corrections and comments on the manuscript of the paper. 


\section{REFERENCES}

Ahadnejad V., Valizadeh M.V., Deevsalar R., Rezaei-Kahkhaie M. (2011) Age and geotectonic position of the Malayer granitoids: implication for plutonism in the Sanandaj-Sirjan Zone, W Iran. Neues Jahrbuch für Geologie und Paläontologie Abhandlungen, 261 (1): 61-75.

Ahmadi-Khalaji A., Esmaeily D., Valizadeh, M.V., Rahimpour-Bonab H. (2007) Petrology and geochemistry of the granitoid complex of Boroujerd, Sanandaj-Sirjan Zone, Western Iran. Journal of Asian Earth Sciences, 29 (5-6): 859-877.

Alavi M. (1994) Tectonics of Zagros orogenic belt of Iran: new data and interpretations. Tectonophysics, 229: 211-238.

Alavi M. (2004) Regional stratigraphy of the Zagros fold-thrust belt of Iran and its proforeland evolution. American Journal of Science, 304: 1-20.

Aranovich L.Y., Lavrent'eva I.V., Kosyakova N.A. (1988) Calibration of the biotite-garnet and biotite-orthopyroxene geothermometers corrected for the variable Al level in biotite. Geochemistry International, 25: 50-59.

Aranovich L.Y., Podlesskii K.K. (1989) Geothermobarometry of high-grade metapelites: simultaneously operating reactions. In: Evolution of metamorphic belts (eds. R.A. Cliff, B.W.D. Yardley, J.S. Daly): 45-62. Blackwell Scientific Publications, Oxford.

Arvin M., Pan Y., Dargahi S., Malekzadeh A., Babaei A. (2007) Petrochemistry of the Siah-Kuh granitoid stock southwest of Kerman, Iran: Implications for initiation of Neotethys subduction. Journal of Asian Earth Sciences, 30: 474-479.

Badrzadeh Z. (2002) Petrology of metamorphic rocks of Sarabi-Tueyserkan area: with emphasis on high-grade metamorphic rocks. M.Sc. Thesis (in Persian), Research Institute of Geological Survey of Iran.

Baharifar A.A. (1997) New perspective on petrogenesis of the regional metamorphic rocks of Hamedan area, Iran. M.Sc. Thesis (in Persian), Tarbiat Moallem University, Tehran, Iran.

Baharifar A.A. (2004) Petrology of metamorphic rocks in Hamedan area, Iran. Ph.D. Thesis (in Persian), Tarbiat Moallem University, Tehran, Iran.

Berman R.G. (1991) Thermobarometry using multi-equilibrium calculations: a new technique with petrological applications. Canadian Mineralogist, 29: 833-855.

Berman R.G., Aranovich L.Y. (1996) Optimized standard state and solution properties of minerals: I. Model calibration for olivine, orthopyroxene, cordierite, garnet, and ilmenite in the system $\mathrm{FeO}-\mathrm{MgO}-\mathrm{CaO}-\mathrm{Al}_{2} \mathrm{O}_{3}-\mathrm{TiO}_{2}-\mathrm{SiO}_{2}$. Contributions to Mineralogy and Petrology, 126: 1-22.

Bhattacharya A., Mohanty L., Maji A., Sen S.K., Raith M. (1992) Non-ideal mixing in the phologopite-annite boundary: constraints from experimental data on Mg-Fe partitioning and a reformulation of the biotite-garnet geothermometer. Contributions to Mineralogy and Petrology, 111: 87-93.

Borzouei K. (2012) A study of contact metamorphic rocks of Sarabi area, Tuyserkan, Hamedan. M.Sc. Thesis (in Persian), Bu-Ali Sina University, Hamedan, Iran.

Braud J. (1987) La suture du Zagros au niveau de Kermanshah (Kurdistan Iranian): Reconstitution paleogeographique, evolution geodynamique, magmatique et structurale. Ph.D. Thesis, Paris (Geodiffusion).

Dasgupta S., Sengupta P., Guha D., Fukuoka M. (1991) A refined garnet-biotite $\mathrm{Fe}-\mathrm{Mg}$ exchange geothermometer and its application in amphibolites and granulites. Contributions to Mineralogy and Petrology, 109: 130-137.

Dwivedi S.B. (1996) Non-ideal binary mixing in cordierite: Constraints from experimental data on $\mathrm{Mg}-\mathrm{Fe}$ partitioning in garnet and cordierite and a reformulation of garnet-cordierite geothermometer. Proceedings of Earth and Planetary Sciences, Indian Academy of Science, Earth System Science, 105: 365-377.
Dwivedi S.B., Mohan A., Lal R.K. (1998) Recalibration of the $\mathrm{Fe}-\mathrm{Mg}$ exchange reaction between garnet and cordierite as a thermometer. European Journal of Mineralogy, 10: 281-289.

Dwivedi S.B., Jimmy L., Vanthangliana V., Lal S.N. (2007) A refined garnet-biotite thermometer: constraints from empirically derived Margules parameters for garnet and biotite. Indian Mineralogist, 41: 97-111.

Esna-Ashari A., Tiepolo M., Valizadeh M.V., Hassanzadeh J., Sepahi A.A. (2012) Geochemistry and zircon U-Pb geochronology of Aligoodarz granitoid complex, Sanandaj-Sirjan Zone, Iran. Journal of Asian Earth Sciences, 43: 11-22.

Ferry J. M., Spear F.S. (1978) Experimental calibration of the partitioning of $\mathrm{Fe}$ and $\mathrm{Mg}$ between biotite and garnet. Contributions to Mineralogy and Petrology, 66: 113-117.

Ganguly J., Cheng W., Tirone M. (1996). Thermodynamics of aluminosilicate garnet solid solution: new experimental data, an optimized model, and thermodynamic applications. Contributions to Mineralogy and Petrology, 126: 137-151.

Ghent E.D., Stout M.Z. (1981) Geobarometry and geothermometry of plagioclase-biotite-garnet-muscovite assemblages. Contributions to Mineralogy and Petrology, 76: 92-97.

Henry D.J., Guidotti C.V. (2002) Titanium in biotite from metapelitic rocks: Temperature effects, crystal-chemical controls, and petrologic applications. American Mineralogist, 87: 375-382.

Henry D.J., Guidotti C.V., Thomson J.A. (2005) The Ti saturation surface for low-to-medium pressure metapelitic biotites: implications for geothermometry and Ti substitution mechanisms implications for geothermometry and Ti-substitution mechanisms. American Mineralogist, 90: 316-328.

Hodges K.V., Crowley P.D. (1985) Error estimation and empirical geothermobarometry for pelitic systems. American Mineralogist, 70: 702-709.

Hodges K.V., Spear F.S. (1982) Geothermometry, geobarometry, and the $\mathrm{Al}_{2} \mathrm{SiO}_{5}$ triple point at Mt. Moosilauke, New Hampshire. American Mineralogist, 67: 1118-1134.

Hoisch T.D. (1990) Empirical calibration of six geobarometers for the mineral assemblage quartz + muscovite + biotite + garnet + plagioclase. Contributions to Mineralogy and Petrology, 104: 225-234.

Holdaway M.J. (2000). Application of new experimental and garnet Margules data to the garnet-biotite geothermometer. American Mineralogist, 85: 881-892.

Holland T.J.B., Powell R. (1990). An enlarged and updated internally consistent thermodynamic dataset with uncertainties and correlations; the system $\mathrm{K}_{2} \mathrm{O}-\mathrm{Na}_{2} \mathrm{O}-\mathrm{CaO}-\mathrm{MgO}-\mathrm{MnO}-\mathrm{FeO}-$ $\mathrm{Fe}_{2} \mathrm{O}_{3}-\mathrm{A}_{2} \mathrm{O}_{3}-\mathrm{TiO}_{2}-\mathrm{SiO}_{2}-\mathrm{C}-\mathrm{H}_{2}-\mathrm{O}_{2}$. Journal of Metamorphic Geology, 8: 89-124.

Holland T.J.B., Powell R. (1995) An internally consistent thermodynamic data set with uncertainties and correlation: 2: Data and results. Journal of Metamorphic Geology, 13: 343-37.

Hyndman D.W. (1985) Petrology of igneous and metamorphic rocks. McGraw-Hill, New York.

Irani M. (1993) Petrology of Alvand granitic body and its metamorphic aureole. M.Sc. Thesis (in Persian), Shahid Beheshti University, Tehran, Iran.

Kleemann U., Reinhardt J. (1994) Garnet-biotite thermometry revisited: the effect of $\mathrm{Al}^{\mathrm{Vl}}$ and $\mathrm{Ti}$ in biotite. European Journal of Mineralogy, 6: 925-941.

Koziol A.M., Newton R.C. (1988) Redetermination of the anorthite breakdown reaction and improvement of the plagioclase-garnet- $\mathrm{Al}_{2} \mathrm{SiO}_{5}$-quartz barometer. American Mineralogist, 73: 216-223.

Lindsley D.H. (1983) Pyroxene thermometry. American Mineralogist, 68: 477-493.

Mahmoudi Sh., Corfu F., Masoudi F., Mehrabi B., Mohajjel M. (2011) U-Pb dating and emplacement history of granitoid plutons in the northern Sanandaj-Sirjan zone, Iran. Journal of Asian Earth Sciences, 41: 238-249. 
Masoudi F. (1997) Contact metamorphism and pegmatites development in the region SW of Arak, Iran. Ph.D. Thesis, University of Leeds, UK

McCarthy T.C., Patino-Douce A.E. (1998) Empirical calibration of the silica-Ca-tschermak's anorthite (SCAn) geobarometer. Journal of Metamorphic Geology, 16: 675-686.

Okrusch M. (1969) Die Gneishornfelse um Steinach in der Oberpfalz-Eine phasenpetrologische Analyse. Contributions to Mineralogy and Petrology, 22: 32-72.

Okrusch M. (1971) Garnet-cordierite-biotite equilibria in the Steinach aureole, Bavaria. Contributions to Mineralogy and $\mathrm{Pe}$ trology, 32: 1-23.

Perchuk L.L. (1991) Derivation of a thermodynamically consistent set of geothermometers and geobarometers for metamorphic and magmatic rocks. In: Progress in Metamorphic and Magmatic Petrology (A memorial volume in honor of D. S. Korzhinsky) (ed. L.L. Perchuk): 93-111. Cambridge University Press, Cambridge.

Perchuk L.L., Aranovich L.Y., Podlesskii K.K., Lavrenteva I.V. (1985) Precambrian granulites of the Alden Shield, eastern Siberia USSR. Journal of Metamorphic Geology, 3: 265-310.

Powell R., Holland T.J.B. (2008) On thermobarometry. Journal of Metamorphic Geology, 26: 155-179.

Rashidnejad-Omran N., Emami M.H., Sabzehei M., Rastad E., Bellon H. (2002) Lithostratigraphy and Paleozoic to Paleocene history of some metamorphic complexes from Muteh area Sanandaj-Sirjan Zone (Iran). Comptes Rendus Geosciences, 334 (16): 1185-1191.

Sadeghian M. (1994) Petrology of igneous and metamorphic rocks of Cheshmeh-Ghassaban area, Hamedan. M.Sc. Thesis (in Persian), Tehran University, Tehran, Iran.

Saki A. (2011) Formation of spinel-cordierite-plagioclase symplectites replacing andalusite in metapelitic migmatites of the Alvand aureole, Iran. Geological Magazine, 148: 423-434.

Saki A., Moazzen M., Baharifar A. (2012) Migmatite microstructures and partial melting of Hamadan metapelitic rocks, Alvand contact aureole, western Iran. International Geology Reviews, 54 (11): 1229-1240.

Sepahi A.A. (1999) Petrology of the Alvand plutonic complex with special reference on granitoids. Ph.D. Thesis (in Persian), Tarbiat Moallem University, Tehran, Iran.

Sepahi A.A. (2008) Typology and petrogenesis of granitic rocks in the Sanandaj-Sirjan metamorphic belt, Iran: With emphasis on the Alvand plutonic complex. Neues Jahrbuch für Geologie und Paläontologie Abhandlungen, 247: 295-312.

Sepahi A.A., Whitney D.L., Baharifar A.A. (2004) Petrogenesis of andalusite-kyanite-sillimanite veins and host rocks, Sanandaj-Sirjan metamorphic belt, Hamedan, Iran. Journal of Metamorphic Geology, 22: 119-134.

Sepahi A.A., Jafari S.R., Mani-Kashani S. (2009) Low-pressure migmatites from the Sanandaj-Sirjan metamorphic belt in the Hamedan region, Iran. Geologica Carpathica, 60 (2): 107-119.

Shahbazi H. (2010) Petrology of igneous rocks and migmatitic complex of Alvand and intrusive body of Almogholagh, Hamedan and their genetic relationship. Ph.D. Thesis (in Persian), ShahidBeheshti University, Tehran, Iran.

Shahbazi H., Siebel W., Pourmoafee M., Ghorbani M., Sepahi A.A., Shang C.J., Vousoughi-Abedini M. (2010) Geochemistry and U-Pb zircon geochoronology of Alvand plutonic complex in Sanandaj-Sirjan Zone (Iran): New evidence for Jurassic magmatism. Journal of Asian Earth Sciences, 39: 668-683.

Sheikholeslami R., Bullen H., Emami M.H., Sabzehei M., Pique A. (2003) New structural and $\mathrm{K}^{40}-\mathrm{Ar}^{40}$ data for the metamorphic rocks in Neyriz area (Sanandaj-Sirjan Zone, southern Iran): Their interest for an overview of the Neo-Tethyan domain in the Middle East. Comptes Rendus Geosciences, 335 (13): 981-991.

Thompson A.B. (1976) Mineral reactions in pelitic rocks: II. Calculation of some P-T-X(Fe, Mg) phase relations. American Journal of Science, 276: 425-454.

Tork H. (2011) A study of petrogenesis of metamorphic rocks from southwest of Tueyserkan. M.Sc. Thesis (in Persian), Bu-Ali Sina University, Hamedan, Iran.

Valizadeh M.V., Cantagrel J.M. (1975) Premieres données radiometriques ( $\mathrm{K}-\mathrm{Ar}$ et $\mathrm{Rb}-\mathrm{Sr}$ ) sur les micas du complexe magmatique du Mont Alvand prés Hamedan (Iran Occidental).Comptes Rendus de l'Académie des Sciences de Paris. Série D 281: 1083-1086.

Whitney D.L., Evans B.W. (2010) Abbreviations for names of rock-forming minerals. American Mineralogist, 95:185-187.

Zareiyan S., Forghani A., Fayyaz H. (1971-1974) Alvand granitic body and its aureole (part 1-6). Journal of Science University of Tehran (in Persian), Serial papers in Volumes 3-6. 